\title{
A Comparative Evaluation of Oysters, Mussels and Sediments as Indicators of Trace Metals in Hong Kong Waters
}

\author{
D. J. H. Phillips ${ }^{1}$ and W. W.-S. Yim ${ }^{2}$ \\ ${ }^{1}$ Environmental Protection Agency, Empire Centre, Kowloon, Hong Kong \\ ${ }^{2}$ Department of Geography and Geology, Hong Kong University, Hong Kong
}

\begin{abstract}
Oysters (Saccostrea glomerata $=$ Crassostrea glomerata Gould) taken from 20 locations revealed considerable contamination of the heavily urbanised Victoria Harbour area by copper and zinc. Data for copper and zinc in sediments, based on samples from 210 sites, confirmed this finding. In addition, mussels (Septifer bilocularis [L.]) were collected twice from 23 locations. Copper concentrations in the mussels were in qualitative agreement with the profiles derived from oyster and sediment investigations. However, the relative enrichment of samples from Victoria Harbour and those from elsewhere was less in mussels than in oysters and sediments, suggesting partial regulation of copper by mussels. Zinc was regulated by the mussels to a much greater extent, differences in zinc concentration between groups of samples or individual samples being minimal. No parallelism existed between oyster, sediment and mussel results with respect to iron levels in the coastal environment of Hong Kong; presumably, the kinetics of iron differ considerably in the 2 bivalve species. We propose that $S$. bilocularis is unsuitable as an indicator organism of trace metals due to partial or complete metabolic regulation. Future studies in the tropics should be cognizant of this possibility when employing other previously unstudied bivalve species as bio-indicators.
\end{abstract}

\section{INTRODUCTION}

The rapid agricultural and industrial development of sub-tropical and tropical nations has given rise to a need for pollutant monitoring programmes in the marine environments of these regions. Such programmes may employ various methods to quantify pollutants, including the analysis of water, sediment samples, and biological indicators. Phillips (1977, 1978, 1980) reviewed the use of biological indicators to monitor trace metals and organochlorines and concluded that such organisms may have advantages over classical methods of water and sediment analysis in certain instances. However, it was emphasised that the organism used must not regulate its pollutant content to any great extent, and that sampling of biota should take into account the influence of various factors, such as condition, size and sex.

The present report presents data from studies using sediments and bivalve molluscs as indicators of trace element pollution in Hong Kong waters. Previous research on the rock oyster Saccostrea glomerata was considered to have defined the general availability of metals in the region (Phillips, 1979). Confirmation of these data has been sought from surveys of copper, iron and zinc in sediments and in the mussel Septifer bilocularis. In addition, a second survey of these metals in Saccostrea glomerata was performed to investigate seasonal changes in the profiles of contamination exhibited by this organism.

\section{MATERIALS AND METHODS}

\section{Bivalves}

Samples of Saccostrea glomerata (= Crassostrea glomerata Gould; see Phillips, 1979) were collected at 20 sites in Hong Kong coastal waters during August 1978. Each of the 20 locations was identical to a location sampled in the previous survey in March or April 1978 (Phillips, 1979). The collection sites are shown (A to $\mathrm{V}$ ) in Fig. 1; all major sectors of Hong Kong waters are included. 
In addition, the mytilid Septifer bilocularis (L.) was taken from 23 locations (Fig. 1, 1-23). Each of these locations was sampled twice, at the same periods as those chosen for the collection of oysters (March/April 1978 and August 1978). These periods were selected as they are representative of the 2 major seasons in Hong Kong: March/April marks the end of the cool, dry winter; August represents the latter part of the hot, wet summer. It was considered that seasonal differences should be maximal in these 2 collections as a result of the climatic variation and associated changes in runoff.

Unfortunately, the differing spatial distributions of the 2 species studied did not permit their collection from identical sites in all cases. Whilst the oyster exhibits a preference for sheltered, estuarine habitats, the mussel prefers conditions of higher salinity and more exposure. Most of the mussel samples were thus derived from waters close to Hong Kong Island and in the southern coastal area, whereas oysters were also taken from the more estuarine areas in the west and north-west (subject to freshwater discharge from the Pearl River, running through Canton, and Deep Bay) and the embayments of the east and north-east.

The sampling, preparatory and analytical procedures employed were identical to those used previously (Phillips, 1979) in all respects. Ten individuals of each species were analysed from each location. The byssus of mussels was discarded. All results quoted refer to whole soft parts of the species studied and are based on dry tissue weights throughout.

\section{Sediments}

Surficial sea-floor sediments from 210 stations were collected using a Smith-McIntyre grab from September 1975 to February 1977. The location of the majority of the samples followed a grid pattern with variable spacing ranging from about $1 \mathrm{~km}$ in inshore areas to more than $4 \mathrm{~km}$ in offshore regions. Positions were fixed by radar.

In the laboratory, visual observations were made on colour, grain size and composition of each sediment sample. Subsamples of $0.5-1.0 \mathrm{~kg}$ were then placed in ceramic mortars for drying at $80^{\circ} \mathrm{C}$. The dried samples were gently disaggregated with a ceramic pestle and the sediment fraction passing through a $170 \mu \mathrm{m}$ (approximately 85 mesh BSS) nylon sieve was used for analysis. A $0.3 \mathrm{~g}$ sample of the $-170 \mu \mathrm{m}$ fraction was digested in a $4: 1 \mathrm{v} / \mathrm{v}$ nitric:perchloric acid mixture and the residue subjected to leaching in molar hydrochloric acid. Elements were determined by flame atomic absorption spectrophotometry, solutions being diluted as necessary. Standards, blanks and duplicates were randomly inserted into sample batches to provide quality control. The precision of the method was better than $\pm 15 \%$ at the $95 \%$ confidence level.

\section{Statistical Treatment (Mussels)}

The profiles of contamination produced by the 2 surveys of metals in the mussel Septifer bilocularis were considered to require statistical treatment in order to test for significant differences between groups of samples. To permit this, Hong Kong waters were divided into 4 zones (Fig. 1), differing in their hydrology or exposure to industrial or domestic wastes. The Western Zone is dominated by brackish waters derived from the Pearl River, which runs through Canton to the north-west of Hong Kong. The Victoria Harbour Zone accepts the majority of effluents generated in Hong Kong Island and Kowloon. In contrast, the Eastern and Southern Zones are relatively unpolluted, differing from each other mainly in their degree of exposure to oceanic waters rather than in their urban development. Results for each element in the mussels sampled have been grouped according to zone, and subjected to comparisons using the non-parametric Kruskal-Wallis test. In each case, the test was used to determine whether significant differences existed between element levels in samples from Victoria Harbour and those in samples from 1 of the other 3 zones.

\section{RESULTS}

\section{Bivalves}

Table 1 presents mean concentrations of copper, iron and zinc in the whole soft parts of oysters, Saccostrea glomerata, from the 20 sites sampled in August 1978. These data are compared in Fig. 2 to the results from the same sites in the previous collection in March/ April 1978 (data from Phillips, 1979). Locations are plotted in alphabetical order from left to right on the horizontal axis; this matches the numerical order in the previous survey and permits the differentiation of metal levels in oysters from distinct areas. It is clear that both copper and zinc were highly enriched in oysters from Victoria Harbour in both surveys. Differences between the 2 surveys were not substantial for these elements, demonstrating that seasonal fluctuations are minimal for copper and zinc in Hong Kong oysters. In contrast, the major facet of the profile for iron in oysters from the first survey - its enrichment in samples from Victoria Harbour - was altogether absent from the data for the second survey. Iron levels in oysters were thus significantly influenced by season in a location-dependent fashion. 
Fig. 1 Saccostrea glomerata and Septifer bilocularis. Sampling locations for oysters and mussels in Hong Kong waters. Oysters were taken from 20 sites labelled A to V. Mussels were taken from 23 sites in 4 Zones: Western (1-6); Victoria Harbour (7-13); Eastern (14-17) and Southern (18-23). Dotted lines: boundaries of each Zone. Insert: Hong Kong in relation to southern China and Canton

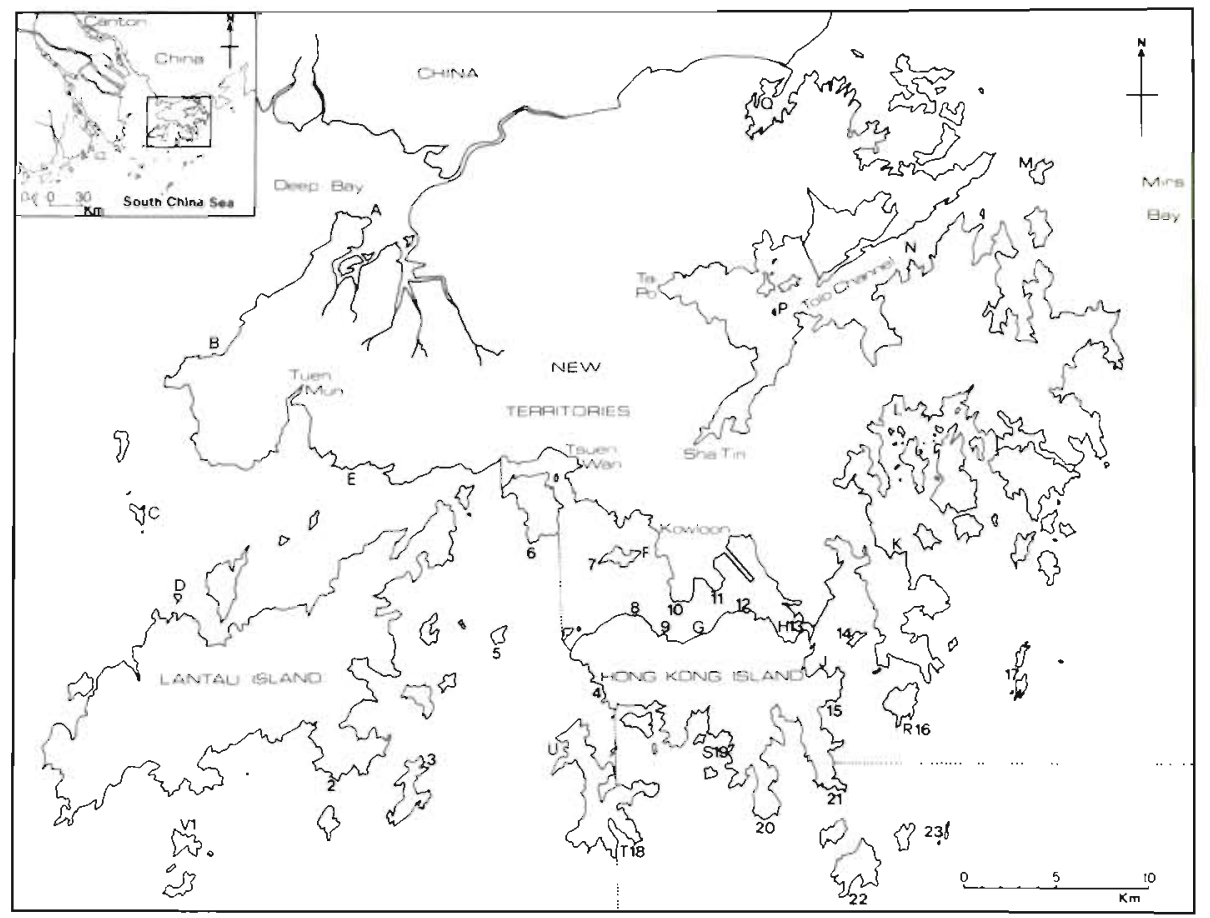

Concentrations of copper, iron and zinc in the whole soft parts of mussels, Septifer bilocularis, from the 23 study locations sampled in March/April and August 1978 are shown in Table 2. A comparison of the overall

Table 1 Saccostrea glomerata. Mean concentrations of copper, iron and zinc ( $\mu \mathrm{g} \mathrm{g}^{-1} \mathrm{dry}$ weight) in whole soft parts of oysters from 20 locations in Hong Kong coastal waters. All samples taken in August 1978; locations identical to those of the same names in Phillips (1979) and shown in Fig. 1

\begin{tabular}{|lrrrr}
\hline \multirow{2}{*}{ Code Location } & Copper & Iron & Zinc \\
\cline { 4 - 5 } A & Deep Bay, Tsim Bei Tsui & 824 & 353 & 3551 \\
B & Deep Bay, south & 819 & 326 & 3889 \\
C & Sha Chau & 564 & 360 & 3856 \\
D & Lam Chau & 344 & 204 & 1989 \\
E & Cedric Bridge & 560 & 283 & 6540 \\
F & Stonecutters Island, east & 993 & 212 & 5136 \\
G & Wanchai & 1673 & 299 & 7479 \\
H & Lei Yu Mun & 735 & 197 & 5349 \\
J & Chai Wan & 1742 & 218 & 7691 \\
K & Silverstrand & 609 & 172 & 5216 \\
L & Tso Wo Hang & 253 & 111 & 1610 \\
M & Tolo, Chek Chau & 371 & 219 & 3164 \\
N & Tolo, Knob Reef & 186 & 129 & 2209 \\
P & Tolo, Centre Island & 163 & 148 & 1695 \\
Q & Starling Inlet & 654 & 238 & 3575 \\
R & Tung Lung, south & 488 & 76 & 2621 \\
S & Repulse Bay & 564 & 205 & 3340 \\
T & Sham Wan & 294 & 68 & 2080 \\
U & Yung Shue Wan & 391 & 135 & 2961 \\
V & Soko Islands, north & 253 & 107 & 1759 \\
& Mean tstandard error: & 624 & 203 & 3785 \\
& $\quad \pm 435$ & \pm 8 & \pm 1883 \\
& & & & \\
\hline
\end{tabular}

means for each element shows that some degree of seasonal fluctuation of metal levels occurred. Thus concentrations of copper and iron decreased on average by $32 \%$ and $62 \%$ respectively in the period between the 2 surveys. In contrast, concentrations of zinc increased slightly, to average $11 \%$ higher in August than in the first survey. Differences in metal levels of mussels from different areas were somewhat less marked than those for oysters; hence the mussel samples were grouped according to area (Fig. 1) and subjected to statistical comparisons using the KruskalWallis test. The results of these tests are also shown in Table $2 ;$ in all cases, element levels in mussels from Victoria Harbour were compared to those in mussels from one of the other 3 regions. In both surveys significantly greater concentrations of copper were present in mussels from Victoria Harbour than in those of any other area. Levels of iron in mussels from Victoria Harbour were also significantly higher than those in mussels from other areas, with the exception of the Southern waters in the second survey. In contrast, concentrations of zinc in mussels from the 3 areas were significantly different from those in mussels from Victoria Harbour only in the case of the sample from the Western zone in the first survey. In all other instances, no significant variation in zinc levels could be found with sampling area.

\section{Sediments}

Concentrations of copper, iron and zinc in the 210 samples of surficial sediments are represented dia- 
Fig. 2. Saccostrea glomerata. Mean concentrations $\left(\mu \mathrm{g} \mathrm{g}^{-1}\right.$ dry weight) of copper, iron and zinc in oysters from 20 sampling locations in Hong Kong waters. Continuous lines: data from present survey. Dashes: results from previous study (Phillips, 1979). Locations shown in Fig. 1
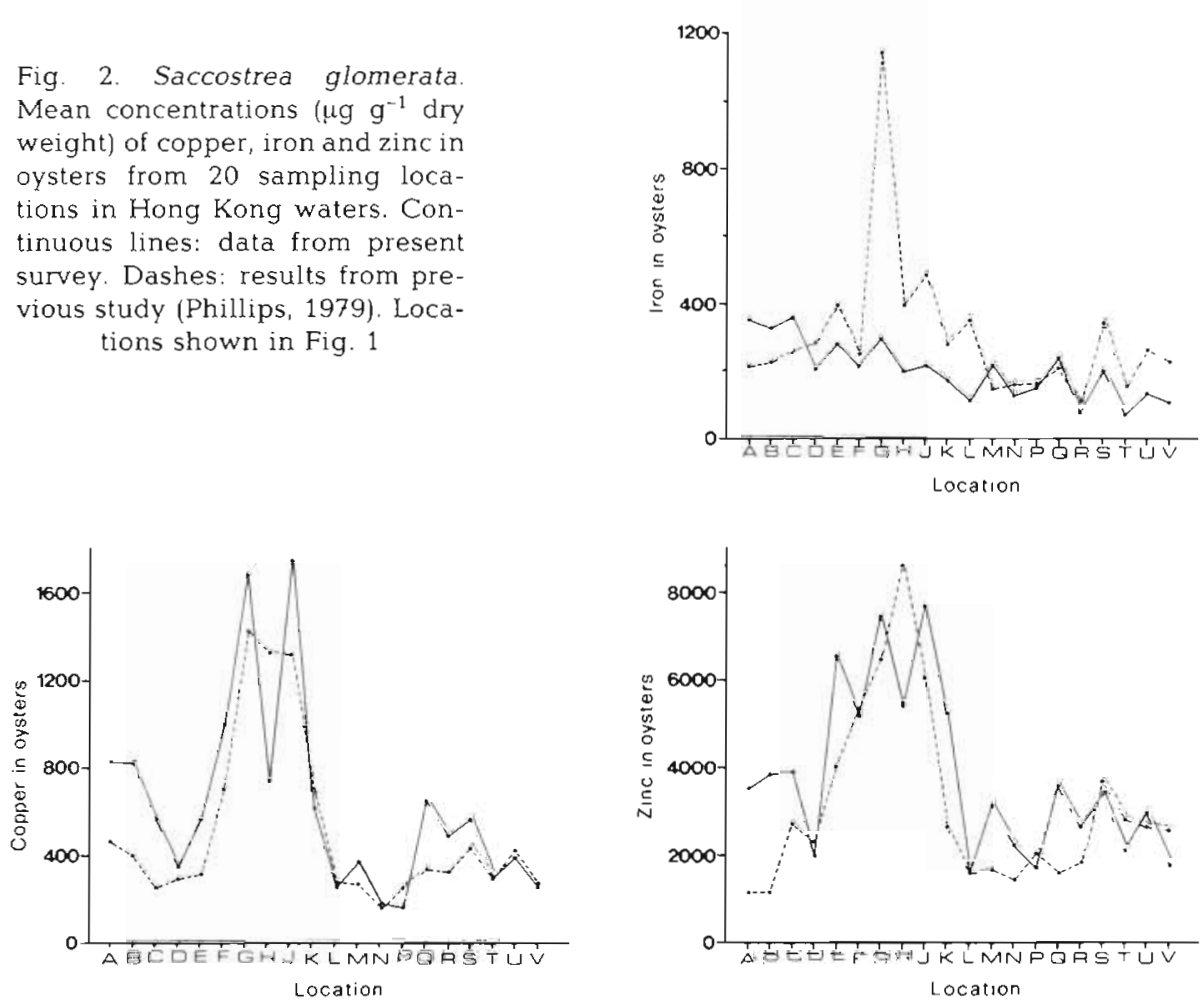

Table 2. Septifer bilocularis. Mean concentrations of copper, iron and zinc ( $\mu \mathrm{g} \mathrm{g}^{-1}$ dry weight) in whole soft parts of mussels from 23 locations in Hong Kong waters. Sampling dates: March/April 1978 for Survey 1, August 1978 for Survey 2. Locations numbered as in Fig. 1. Levels of significance refer to tests of mussels from each location against those from Victoria Harbour in the same survey

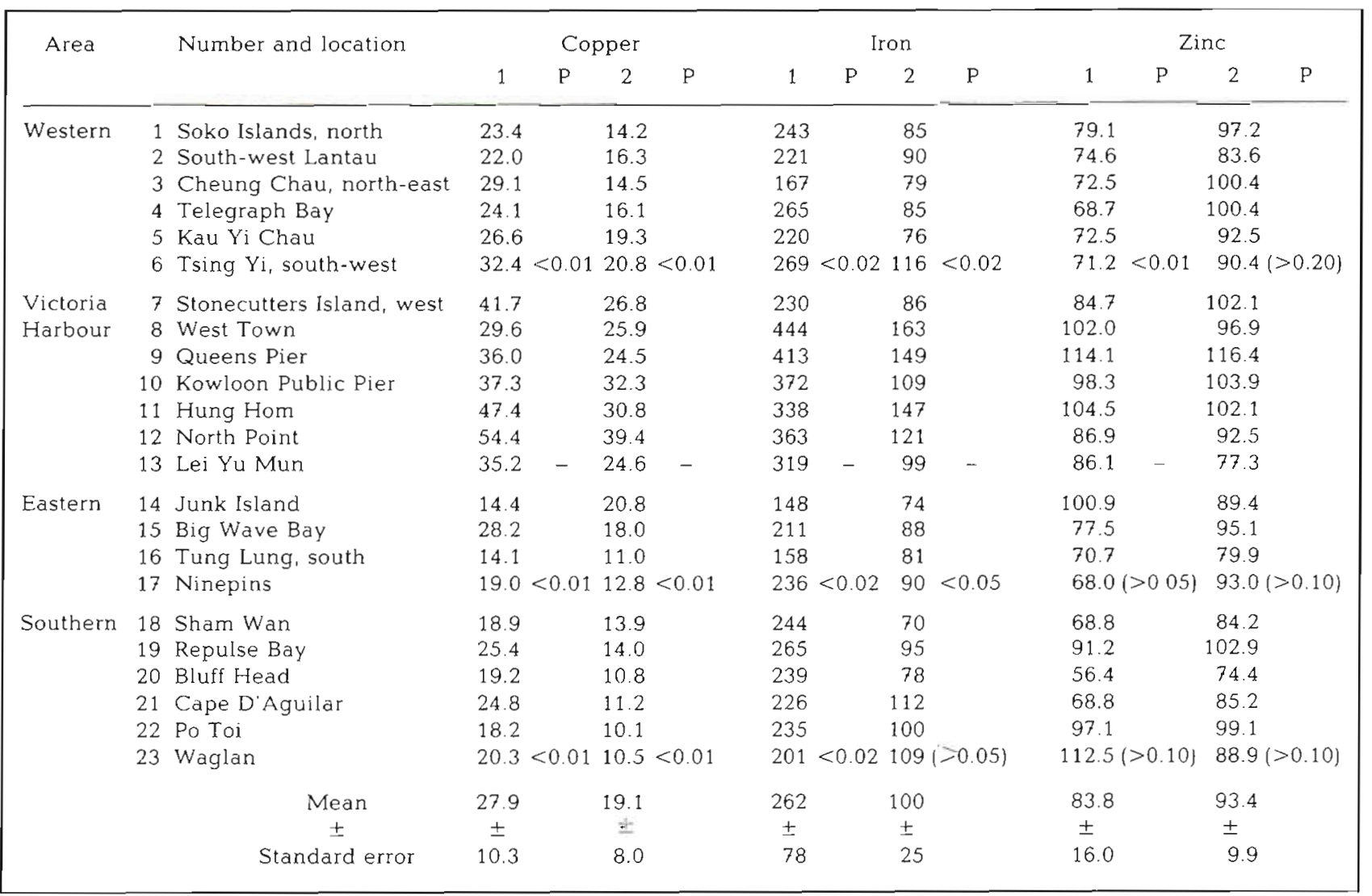


Fig. 3. Mean concentrations of copper ( $\mu g \mathrm{~g}^{-1}$ dry weight) in $-170 \mu \mathrm{m}$ fraction of surficial sedjments from 210 sites in Hong Kong waters. Data shown in terms of 8 intervals in concentration (see insert). For place names consult Fig. 1

grammatically in Figs. $3-5$. It is immediately evident that levels of both copper and zinc were considerably elevated in sediments from Victoria Harbour compared to other areas. Overall averages for these elements in Victoria Harbour locations compared to other areas (based on delineation of Victoria Harbour as shown in Fig. 1 and all quoted as $\mu \mathrm{g} \mathrm{g}^{-1}$ dry weight) were as

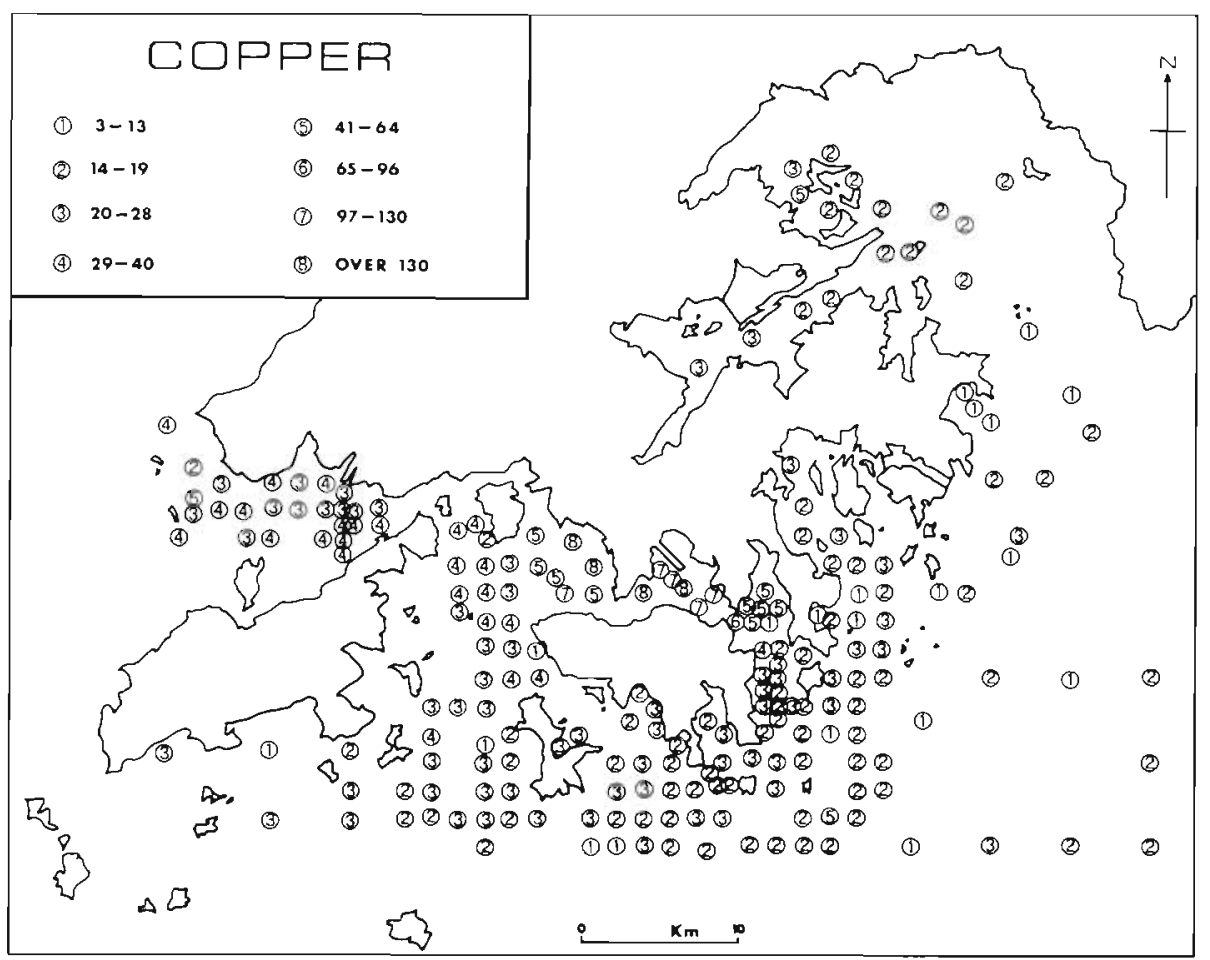

follows: Victoria Harbour, $111 \mu \mathrm{g} \mathrm{g} \mathrm{g}^{-1} \mathrm{Cu} ; 247 \mu \mathrm{g} \mathrm{g}$ $\mathrm{Zn}$; all other areas combined, $22 \mu \mathrm{g} \mathrm{g}{ }^{-1} \mathrm{Cu} ; 96 \mu \mathrm{g} \mathrm{g}^{-1}$ $\mathrm{Zn}$. On average, therefore, Victoria Harbour sediments were 5 -fold more contaminated by copper and 2.5-fold more enriched by zinc than sediments in other areas. In contrast, iron levels in Victoria Harbour sediments (averaging $31650 \mu \mathrm{g} \mathrm{g}^{-1}$ dry weight) were almost iden-
Fig. 4. Mean concentrations of iron ( $\mu \mathrm{g} \mathrm{g}^{-1} \mathrm{dry}$ weight) in -170 um fraction of surficial sediments from 210 sites in Hong Kong waters. Data shown in terms of 7 intervals in concentration (see insert). For place names consult Fig. 1

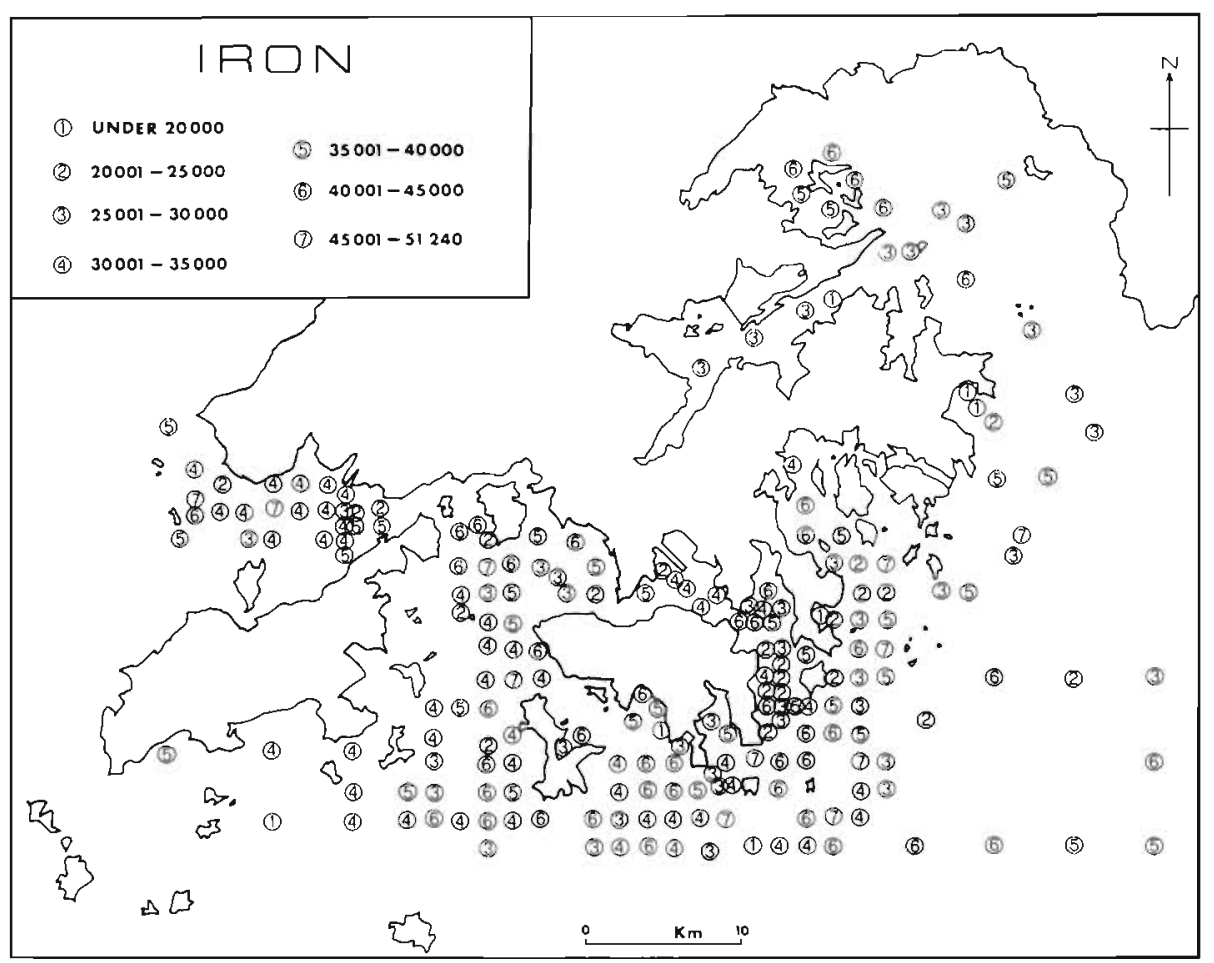




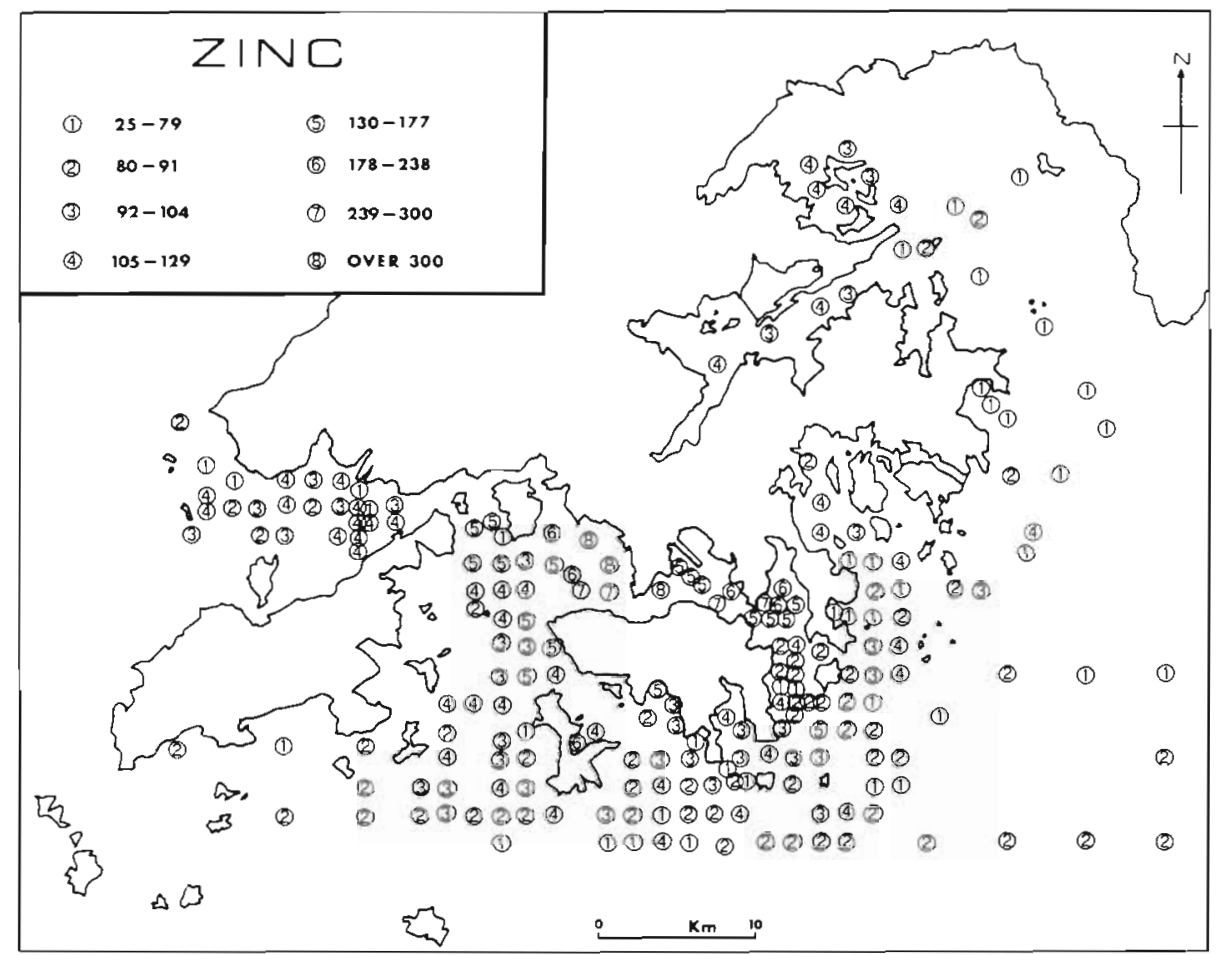

Fig. 5. Mean concentrations of zinc ( $\mu \mathrm{g} \mathrm{g}^{-1}$ dry weight) in -170 fum fraction of surficial sediments from 210 sites in Hong Kong waters. Data shown in terms of 8 intervals in concentration (see insert). For place names consult Fig. 1 tical to those in sediments elsewhere in Hong Kong waters (mean of $33123 \mu \mathrm{g} \mathrm{g}^{-1}$ dry weight); this similarity is evident in Fig. 4.

\section{DISCUSSION AND CONCLUSIONS}

Detailed inventories of discharges of trace metals to Hong Kong coastal waters do not exist at present, and no detailed studies of element levels in water around Hong Kong have been undertaken. Despite this, it is possible to gauge the probable levels of gross pollution by considering the distribution of the population, which correlates approximately to the density of industry. The majority of the population is concentrated in

Table 3. Population estimates in various parts of Hong Kong, Kowloon and the New Territories. Data are for 1981, estimated after the previous census. (After Watson and Watson, 1971)

\begin{tabular}{lr|}
\hline \multicolumn{1}{|c|}{ Area } & $\begin{array}{c}\text { Estimated } \\
\text { population }\end{array}$ \\
\hline Hong Kong Island/Kowloon & $3,770,000$ \\
Tsuen Wan & 700,000 \\
Tuen Mun & 130,000 \\
Sha Tin & 115,000 \\
Tai Po & 42,000 \\
Other built-up areas & 116,000 \\
Rural and marine & 272,000 \\
Total & \\
\hline
\end{tabular}

the Kowloon peninsula and on the northern shore of Hong Kong Island; sewage and industrial effluents from this area enter Victoria Harbour, generally with little or no pretreatment. Estimates of the comparative population of this area with others in Hong Kong, Kowloon and the New Territories clearly show this asymmetry of discharges (Table 3). Apart from the area surrounding Victoria Harbour, significant industrial and domestic pollution may be expected in the areas of the new satellite towns (Fig. 1) of Tsuen Wan, Tuen Mun, and inner Tolo Harbour (Sha Tin and Tai Po); however, none of these areas approaches the population surrounding Victoria Harbour.

Data from both surveys of copper and zinc in the oyster Saccostrea glomerata match the population distribution well, clearly showing greater availability of these metals in the Victoria Harbour area (Phillips, 1979, and Fig. 2). Seasonal variation between the two surveys for these metals was minimal and the observed changes in profiles in Fig. 2 may be ascribed to local variation in discharges. Iron levels, however, altered radically in oysters from Victoria Harbour between the two surveys. Whether this is due to variation in the local availability of iron is unclear, although the lack of significant changes in the iron levels of oysters from the other study locations supports such a hypothesis. Frazier (1975) found iron to be much more labile than copper or zinc in the American oyster Crassostrea virginica because of deposition of large amounts of the former element in the shell. The same may be true of S. glomerata. 
Profiles for the contamination of sediments by copper and zinc match those of oysters. Maximum contamination is again evident in the densely populated Victoria Harbour area, with ratios of element concentrations to those in other locations being generally similar to those found for vysters. Profiles for iron in sediments, however, revealed no enrichment of this metal in Victoria Harbour. Data for iron in sediments thus match the profile seen in the second survey of oysters (Fig. 2, continuous lines). The differences between these 2 profiles and that seen in oysters in the earlier survey are unexplained, although the influence of seasonal shell deposition, noted by Frazier (1975) for Crassostrea virginica and discussed above, may play a role. Alternatively, the speciation of iron or its biological availability may alter seasonally in Hong Kong, perhaps in concert with salinity changes. Whatever the explanation, it is clear that the indicator ability of Saccostrea glomerata for iron is far from proven.

The data for trace elements in Septifer bilocularis sampled in the present study are particularly interesting. $S$. bilocularis is a mytilid, and as such might be expected to be a useful indicator organism, perhaps even a tropical counterpart to Mytilus edulis. No previously published data on element levels in this species could be found; hence brief comments on the absolute levels of metals in the present samples are warranted. Typical concentrations of copper in species of the genera Mytilus, Modiolus and Perna are shown in Table 4. with the present data for $S$. bilocularis for comparison. It is evident that $S$. bilocularis exhibits no particularly unusual trends in terms of its retention of these elements, the ranges in concentration of each element being similar to those reported for other mytilids. However, it might be noted here that unusually high nickel levels are present in S. bilocularis (Phillips, unpubl.); samples from Hong Kong have exhibited $12-46 \mu \mathrm{g} \mathrm{g}^{-1}$ dry weight for this element in whole soft parts. This is generally much greater enrichment than that found for nickel in species of Mytilus, although Segar et al.
(1971) reported $9-133 \mu \mathrm{g} \mathrm{g}^{-1}$ dry weight for this element in Modiolus modiolus from the Irish Sea.

The profiles of contamination exhibited by Septifer bilocularis are best examined by the statistical comparisons of element levels in mussels from Victoria Harbour to those in mussels from waters elsewhere (Table 2). On the basis of data from the sediment and oyster surveys, relatively greater enrichment of both copper and zinc would be anticipated in mussels from the Victoria Harbour area. For copper, concentrations exhibited by mussels are indeed greater in the Harbour area than elsewhere, in both surveys. However, the relative degree of enrichment was not as great in the mussels as in either oysters or sediments. Although sampling locations varied for the 3 surveyed components, the smaller relative enrichment of mussels by copper in Victoria Harbour does not appear to be an artefact of the locations sampled. In the case of zinc, statistical comparisons could demonstrate no consistent enrichment of mussel samples from Victoria Harbour compared to those taken elsewhere. Finally, iron concentrations tended to be greater in mussels from Victoria Harbour than in those from other waters in both surveys.

It appears from these comparisons that several differences exist between the profiles from mussel studies and those from the analysis of oysters and sediments. Whilst qualitative agreement of the 3 survey types was attained for copper, the different relative enrichments of samples suggests possible partial regulation of this element in Septifer bilocularis. In the case of zinc, metabolic regulation by mussels appears almost complete, samples from waters differing considerably in their zinc content (as judged by population and industry densities, sediment studies, and oyster analysis) exhibiting very similar concentrations within the mussels' soft tissues. It might also be noted that the lack of significant seasonal variation in zinc concentrations of $S$. bilocularis also supports the concept of metabolic regulation of this element (Table 2). However, the

Table 4. Typical values reported for the concentrations of copper, iron and zinc ( $\mu \mathrm{g} \mathrm{g}^{-1} \mathrm{dry}$ weight) in whole soft parts of mussels of the genera Mytilus, Modiolus and Perna, compared to data from the present study on Septifer bilocularis

\begin{tabular}{|c|c|c|c|c|c|}
\hline Species & Location & Copper & Iron & Zinc & Source \\
\hline \multirow[t]{4}{*}{ Mytilus edulis } & Tasman Bay, New Zealand & 9 & 1960 & 91 & Brooks and Rumsby (1965) \\
\hline & The Solent, U.K. & 10 & 1700 & 91 & Segar et al. (1971) \\
\hline & Poole Harbour, U.K. & $7-11$ & $87-154$ & $94-162$ & Boyden (1975) \\
\hline & Port Phillip Bay, Australia & $3-11$ & No data & $126-747$ & Phillips (1976b) \\
\hline Mytilus galloprovincialis & N.W. Mediterranean Sea & $2-154$ & $149-2220$ & $97-644$ & Fowler and Oregioni (1976) \\
\hline Mytilus californianus & California, USA & $9-30$ & No data & $164-310$ & Graham (1972) \\
\hline Modiolus modiolus & Irish Sea & $10-44$ & $300-350$ & $320-530$ & Segar et al. (1971) \\
\hline Perna canaliculus ${ }^{\bullet}$ & Coasts of New Zealand & $1-187$ & $173-1867$ & $3-187$ & Nielsen and Nathan (1975) \\
\hline Septifer bilocularis & Coasts of Hong Kong & $10-54$ & $70-444$ & $56-116$ & Present study \\
\hline
\end{tabular}


situation for iron is less clear, as no consistent agreement between results from any of the surveys was attained. It would seem likely that seasonal speciation changes (affecting bioavailability of iron and its loss to sediments) are involved. In addition, differences in iron kinetics in the 2 bivalve species may be present, particularly with respect to the loss of iron to the shell in the oyster and to the byssus in the mussel (Frazier, 1975, c.f. George et al., 1976; George and Coombs, 1977)

The existence of metabolic regulation of certain elements in bivalve molluscs has been suspected previously. Phillips (1980) suggested on the basis of data of Manly and George (1977) that certain elements might be regulated to within definite limits in the freshwater mussel Anodonta anatina. Partial regulation of copper levels in Mytilus edulis has also been proposed (Scott and Major, 1972; Phillips, 1976a, b, 1980; Davenport 1977; Davenport and Manley, 1978). The existence of metal-metal interactions in some bivalves (e.g. Romeril, 1971; Fowler et al., 1975; Jackim et al., 1977; Luoma and Bryan, 1978) also demonstrates that element levels may be metabolically influenced under certain circumstances. It is clear from these reports and from data on Septifer bilocularis in the present study that any assumption concerning the indicator ability (lack of metal regulation) in bivalve species which have not been studied previously is tenuous at best. This finding has important repercussions in tropical areas, where little-known species are currently under consideration for monitoring trace metals and other pollutants in coastal waters. It is proposed that the expenditure of large sums of money on international or national monitoring programmes in these areas should be prefaced by less ambitious local investigations designed to confirm the usefulness of any particular species as an indicator organism.

Acknowledgements. We wish to thank the following for their help in production of these data: Dr G. B. Thompson, for providing sediment samples; Professor D. S. Payne, for use of the analytical instrument; P. S. Nau. S. W Nam and Miss L. Loh, for laboratory assistance; Miss Y.-L. Sin, Mrs. S. Lee and M.-S. Yiu, for preparation of figures; Miss L. Chan, for typing the manuscript. The Director of Agriculture and Fisheries and the Commissioner for Environmental Protection in Hong Kong have kindly permitted us to publish these data.

\section{LITERATURE CITED}

Boyden, C. R. (1975). Distribution of some trace metals in Poole Harbour, Dorset. Mar Pollut. Bull. 6 (12): 180-187

Brooks, R. R., Rumsby, M. G. (1965). The biogeochemistry of trace element uptake by some New Zealand bivalves. Limnol. Oceanogr 10:521-528
Davenport, J. (1977). A study of the effects of copper applied continuously and discontinuously to specimens of Mytilus edulis (L.) exposed to steady and fluctuating salinity levels. J. mar. biol. Ass. U. K. 57:63-74

Davenport, J., Manley, A. (1978). The detection of heightened sea-water copper concentrations by the mussel Mytilus edulis. J. mar biol. Ass. U. K. 58: 843-850

Fowler, B. A., Wolfe, D. A., Hettler, W. F. (1975). Mercury and iron uptake by cytosomes in mantle epithelial cells of quahog clams (Mercenaria mercenaria) exposed to mercury. J. Fish. Res. Bd Can. 32: 1767-1775

Fowler, S. W., Oregioni, B. (1976). Trace metals in mussels from the N. W. Mediterranean. Mar. Pollut. Bull. 7 (2): 26-29

Frazier, J. M. (1975). The dynamics of metals in the American oyster, Crassostrea virginica. I. Seasonal effects Chesapeake Sci. 16: 162-171

George, S. G., Coombs, T. L. (1977). Effects of high stability iron-complexes on the kinetics of iron accumulation and excretion in Mytilus edulis (L.). J. exp. mar. Biol. Ecol. 28: $133-140$

George, S. G., Pirie, B. J. S., Coombs, T. L. (1976). The kinetics of accumulation and excretion of ferric hydroxide in Mytilus edulis (L.) and its distribution in the tissues. J. exp. mar. Biol. Ecol. 23: 71-84

Graham, D. L. (1972). Trace metal levels in intertidal molluscs of California. Veliger 14:365-372

Jackim, E., Morrison, G., Steele, R. (1977). Effects of environmental factors on radiocadmium uptake by four species of marine bivalves. Mar. Biol. 40: 303-308

Luoma, S. N., Bryan, G. W (1978). Factors controlling the availability of sediment-bound lead to the estuarine bivalve Scrobicularia plana. J. mar. biol. Ass. U. K. 58; 793-802

Manly, R., George, W O. (1977). The occurrence of some heavy metals in populations of the freshwater mussel Anodonta anatina (L.) from the River Thames. Environ. Pollut. 14: 139-154

Nielsen, S. A., Nathan, A. (1975). Heavy metals in New Zealand molluscs. N. Z. Jl mar. Freshwat. Res. 9: 467-481

Phillips, D. J. H. (1976a). The common mussel Mytilus edulis as an indicator of pollution by z:nc, cadmium, lead and copper I. Effects of environmental variables on uptake of metals. Mar Biol. 38: 59-69

Phillips, D. J. H. (1976b). The common mussel Mytilus edulis as an indicator of pollution by zinc, cadmium, lead and copper. II. Relationship of metals in the mussel to those discharged by industry. Mar Biol. 38: $\overline{7} 1-80$

Phillips, D. J. H. (1977). The use of biological indicator organisms to monitor trace metal pollution in marine and estuarine environments - a review. Environ. Pollut. 13: 281-317

Phillips, D. J. H. (1978). Use of biological indicator organisms to quantitate organochlorine pollutants in aquatic environments - a review. Envirom. Pollut. 16: 167-229

Phillips, D. J. H. (1979). The rock oyster Saccostrea glomerata as an indicator of trace metals in Hong Kong. Mar. Biol. 53: $353-360$

Phillips, D. J. H. (1980). Quantitative aquatic biological indicators: Their use to monitor trace metal and organochLorine pollution, Applied Sclence Publishers Ltd., London

Romeril, M. G. (1971). The uptake and distribution of $\mathrm{Zn}^{65}$ in oysters. Mar Biol. 9: 347-354

Scott, D. M., Major, C. W. (1972). The effect of copper-II on survival, respiration and heart rate in the common blue mussel, Mytilus edulis. Biol. Bull. mar biol. Lab., Woods Hole 143: 679-688 
Segar, D. A., Collins, J. D., Riley, J. P. (1971). The distributions of the major and some minor elements in marine animals. II. Molluscs. J. mar biol. Ass. U. K. 51 131-136
Watson, J. D., Watson, D. M. (1971). Marine investigation into sewage discharges: report and technical appendices. Report to Government of Hong Kong, July. Hong Kong Government Printer, Hong Kong

This paper was presented by $\operatorname{Dr}$ G. W Bryan; it was accepted for printing on August 10, 1981 